University of Nebraska - Lincoln

DigitalCommons@University of Nebraska - Lincoln

Redescription of Anovia circumclusa (Gorham) (Coleoptera:

Coccinellidae: Noviini), with First Description of the Egg, Larva, and Pupa, and Notes on Adult Intraspecific Elytral Pattern Variation

Juanita A. Forrester

Department of Entomology, University of Georgia, 413 Biological Sciences Building, Athens, Georgia, 30602-2603, juanita.forrester@gmail.com

Natalia J. Vandenberg ystematic Entomology Lab (SEL), Plant Sciences Institute, Agricultural Research Service, USDA, c/o National Museum of Natural History, Smithsonian Institution, P.O. Box 37012, MRC-168, Washington, DC 20013-7012, Natalia.Vandenberg@ars.usda.gov

Joseph V. Mchugh Department of Entomology, University of Georgia, 413 Biological Sciences Building, Athens, Georgia, 30602-2603, mchugh.jv@gmail.com

Follow this and additional works at: https://digitalcommons.unl.edu/systentomologyusda

Part of the Entomology Commons

Forrester, Juanita A.; Vandenberg, Natalia J.; and Mchugh, Joseph V., "Redescription of Anovia circumclusa (Gorham) (Coleoptera: Coccinellidae: Noviini), with First Description of the Egg, Larva, and Pupa, and Notes on Adult Intraspecific Elytral Pattern Variation" (2009). USDA Systematic Entomology Laboratory. 43.

https://digitalcommons.unl.edu/systentomologyusda/43

This Article is brought to you for free and open access by the Entomology Collections, Miscellaneous at DigitalCommons@University of Nebraska - Lincoln. It has been accepted for inclusion in USDA Systematic Entomology Laboratory by an authorized administrator of DigitalCommons@University of Nebraska - Lincoln. 


\title{
Redescription of Anovia circumclusa (Gorham) (Coleoptera: Coccinellidae: Noviini), with first description of the egg, larva, and pupa, and notes on adult intraspecific elytral pattern variation
}

\author{
JUANITA A. FORRESTER ${ }^{1}$, NATALIA J. VANDENBERG ${ }^{2}$, \& JOSEPH V. MCHUGH ${ }^{3}$ \\ ${ }^{1}$ Department of Entomology, University of Georgia, 413 Biological Sciences Building, Athens, Georgia, 30602-2603. \\ E-mail: juanita.forrester@gmail.com \\ ${ }^{2}$ Systematic Entomology Laboratory (SEL), Plant Sciences Institute, Agricultural Research Service, USDA, clo National Museum of \\ Natural History, Smithsonian Institution, P.O. Box 37012, MRC-168, Washington, DC 20013-7012. \\ E-mail: Natalia.Vandenberg@ars.usda.gov \\ ${ }^{3}$ Department of Entomology, University of Georgia, 413 Biological Sciences Building, Athens, Georgia, 30602-2603. \\ E-mail: mchugh.jv@gmail.com
}

\begin{abstract}
Anovia circumclusa (Gorham), a neotropical lady beetle, recently was recorded in North America for the first time. Previously, only the adult form of this beneficial predator had been described. This paper provides a redescription of the adult and the first descriptions of the egg, larva, and pupa. Diagnostic characters for the genus and species are given, and intraspecific color variation in Anovia adults is discussed.
\end{abstract}

Key words: ladybird, lady beetle, coccinellid, larva, morphology, taxonomy, scale predator, color variation

\section{Introduction}

Members of the charismatic beetle family Coccinellidae are well known for their appealing coloration. In agricultural circles, though, they are equally famous for their efficacy as biological control agents. One of the earliest examples of successful biological control involved a lady beetle from the tribe Noviini: Rodolia cardinalis (Mulsant) (Koebele 1892; Olliff 1895). This beetle was imported into the U.S. from Australia in the late $19^{\text {th }}$ century and was instrumental in the protection of California's citrus crops from the cottony cushion scale, Icerya purchasi Maskell (Caltagirone and Doutt 1989). Interest in noviines as biocontrol agents has been renewed by the recent discovery of an introduced pest scale in Florida, Crypticerya genistae (Hempel) (Hodges 2006). Subsequently, a newly introduced noviine, Anovia circumclusa (Gorham) was found feeding on this adventive scale insect (Forrester and Vandenberg 2008). Both predator and prey have been collected from Honduras, Mexico, and Panama, and are apparently native to the Neotropics (Gordon 1972; Gordon 1985; Hodges 2006).

Noviini consists of $\sim 80$ described species and three genera: Anovia Casey, Novius Mulsant, and Rodolia Mulsant. Despite the large number of species, little taxonomic work has focused on immature stages. Of those 80 nominal species, only seven have had immature stages described: Anovia virginalis (Wickham), Novius cruentatus Mulsant, Rodolia koebelei Olliff, R. cardinalis (Mulsant), Rodolia concolor Lewis, Rodolia fausti (Weise) and Rodolia limbata Motschulsky. A review of literature pertaining to larval Noviini is provided in Table 1. Noviine species are effective biocontrol agents as both larvae and adults, so larval descriptions for the tribe are desirable (Rees et al. 1994). 
TABLE 1. Summary of taxonomic literature on Noviini immature stages, parenthetical letters are defined as follows: $\mathrm{e}=$ egg, 1 = larva, $\mathrm{p}=$ pupa.

\begin{tabular}{|c|c|c|c|}
\hline Taxon & Developmental stage, notes & Reference & Pages \\
\hline Noviini & (1) diagnosis & Emden van 1949 & 278 \\
\hline Noviini & (1) diagnosis & Kamiya 1964 & $86-93$ \\
\hline Noviini & (l) key & Kamiya 1966 & $82-83$ \\
\hline Noviini & (p) description, key, illustrations & Phuoc \& Stehr 1974 & $6,19,43,50$ \\
\hline Noviini & (1) diagnosis, key & Sasaji 1968 & $109-110$ \\
\hline Noviini & (1) diagnosis, key & Savoiskaya 1973 & 37,40 \\
\hline Noviini & (l) description, key & Savoiskaya 1983 & 144 \\
\hline Noviini & $(1, \mathrm{p})$ description & Ślipiński 2007 & 141 \\
\hline Noviini & $(1, \mathrm{p})$ description, life history notes & Vandenberg 2002 & 372 \\
\hline Anovia virginalis & (1) diagnosis & Gordon 1972 & 25 \\
\hline Anovia virginalis & (1) description, illustration & Rees 1947 & $118-119$ \\
\hline Anovia virginalis & (l) diagnosis, illustration & Rees et al. 1994 & 404,410 \\
\hline Novius cruentatus & (1) description, illustrations & Klausnitzer \& Shulz 1975 & $359-361$ \\
\hline Novius cruentatus & $(\mathrm{e}, 1, \mathrm{p})$ development, life history & Weise 1887 & $181-183$ \\
\hline Novius cruentatus & (1) description, illustrations, biology & Perris 1862 & 226-229, pl. 6 \\
\hline Rodolia cardinalis & $(\mathrm{e}, 1, \mathrm{p})$ development, life history & Balduf 1935 & $139-146$ \\
\hline Rodolia cardinalis & (1) diagnosis & Gordon 1972 & 25 \\
\hline Rodolia cardinalis & $(e, 1, p)$ photographs, life history & Grafton-Cardwell 2002 & 3 \\
\hline Rodolia cardinalis & (1) diagnosis, illustration & Kamiya 1964 & $86-93$ \\
\hline Rodolia cardinalis & (1) diagnosis & Kamiya 1966 & 82 \\
\hline Rodolia cardinalis & $(\mathrm{e}, 1, \mathrm{p})$ description, illustrations & LeSage 1991 & $485-490$ \\
\hline Rodolia cardinalis & (p) description, illustration & Phuoc \& Stehr 1974 & 6,13 \\
\hline Rodolia cardinalis & $(\mathrm{e}, 1, \mathrm{p})$ description, illustrations & Priore 1963 & $131-161$ \\
\hline Rodolia cardinalis & (1) description, illustrations & Rees 1947 & $117-118$ \\
\hline Rodolia cardinalis & (1) diagnosis, illustration & Rees et al. 1994 & 404,410 \\
\hline Rodolia cardinalis & (1) description, illustration & Sasaji 1968 & $110-111$ \\
\hline Rodolia cardinalis & (l) diagnosis, illustration & Savoiskaya 1973 & 43,45 \\
\hline Rodolia cardinalis & (1) description, illustration & Savoiskaya 1983 & $144-148$ \\
\hline Rodolia concolor & (1) diagnosis & Kamiya 1966 & 83 \\
\hline Rodolia concolor & (1) description & Kawaguchi 1935 & 208 \\
\hline Rodolia concolor & (1) description, illustration & Sasaji 1968 & $112-113$ \\
\hline Rodolia concolor & (1) description, illustration & Savoiskaya 1983 & 148 \\
\hline Rodolia fausti & (1) diagnosis, illustration & Savoiskaya 1973 & 43,45 \\
\hline Rodolia fausti & (1) description, illustration & Savoiskaya 1983 & 145 \\
\hline Rodolia koebelei & (1) description & Rees 1947 & $117-118$ \\
\hline Rodolia limbata & (1) description, illustration & Sasaji 1968 & $111-112$ \\
\hline Rodolia limbata & (l) diagnosis, illustration & Savoiskaya 1973 & 43,45 \\
\hline Rodolia limbata & (1) description, illustration & Savoiskaya 1983 & 146 \\
\hline
\end{tabular}




\section{Materials and methods}

Specimens of all life stages were examined using a Meiji Techno $\mathrm{RZ}^{\circledR}$ stereoscopic microscope. The egg was photographed using a Zeiss ${ }^{\circledast}$ ESEM (Environmental Scanning Electron Microscope). Photographs of the pupal and adult habitus were taken with a Microptics ${ }^{\circledR}$ digital imaging system (Photografix ${ }^{\circledR}$, Inc., Richmond, Virginia) used in conjunction with Combine $Z^{\circledR}$ software. All photographs were edited with Adobe ${ }^{\circledR}$ Photoshop $^{\circledast}$ (Adobe $^{\circledast}$ Systems, Inc., 2003, San Jose, California). Dissections of freshly killed larvae and adults were performed in warm water and $75 \%$ ethanol, respectively. All dissections were slide mounted in glycerol. Illustrations were rendered using a camera lucida attached to a Leitz ${ }^{\circledR}$ DMRB compound microscope (Leica ${ }^{\circledR}$ Microsystems, Inc., Bannockburn, Illinois). Line drawings were rendered using Adobe ${ }^{\circledR}$ Illustrator ${ }^{\circledR}$ CS2 (Adobe ${ }^{\circledR}$ Systems, Inc., 2003, San Jose, California). Label data are provided verbatim, with all line breaks, capitalization, and punctuation recorded exactly. Integumental armature follows the terminology of Gage (1920). All immature specimens were obtained from laboratory-reared cultures maintained by USDA, APHIS, Plant Protection and Quarantine, Miami, Florida.

\section{Anovia Casey 1908}

(Figs. 1-41)

Anovia Casey, 1908: 408. Leng, 1920: 214. Korschefsky, 1931: 96. Gordon, 1972: 26. (Type species: Scymnus virginalis Wickham, by monotypy).

The type species for Anovia was originally described as Scymnus virginalis Wickham, but subsequent authors questioned the placement in Scymnus (Casey 1908). Casey (1908), noting several morphological similarities to both Rodolia Mulsant and Novius Mulsant, erected Anovia to accommodate this species and included all three genera in Exoplectrini. Leng (1920) included Anovia, Novius, and Rodolia in Noviini for the first time.

Diagnosis. Adults of Anovia are diagnosed by the following combination of characters: body convex, subhemispherical dorsum that is widest just posterior to humeral angles (Figs. 17-22); all surfaces including eye facets covered with pale, posteriorly-directed vestiture; eye margin entire, not interrupted by an ocular canthus (Fig. 23); clypeal apex horizontal (Fig. 23); antenna with 8 articles, weakly clubbed (Fig. 25); and tarsi trimerous (Figs. 32-34).

\section{Anovia circumclusa (Gorham)}

(Figs. 1-41)

Zenoria circumclusa Gorham, 1899: 262. Korschefsky, 1931: 108. Blackwelder, 1945: 443. Anovia circumclusa Gordon, 1971: p.1; Gordon, 1972: 27-29. (Type depository: BMNH).

Diagnosis: The larva of this species resembles all other known noviine larvae, but is distinguishable by the presence of many chalazae on the lateral strumae of the abdominal segments ( $R$. cardinalis has 2 , and $R$. koebelei has 4). Anovia circumclusa adults are best recognized by the structure of the male genitalia. In $A$. circumclusa, the basal lobe is slender and does not extend laterally beyond the internal paramere margin, while in all other Anovia species the basal lobe is quite broad distally, and overlaps the medial paramere margin. Also, the basal piece is widest basally in A. circumclusa, not distally as in A. virginalis.

Egg. Length $0.5 \mathrm{~mm}$, width $0.25 \mathrm{~mm}$. Elongate-oval, color bright magenta. Surface granular, often covered with waxy exudate (Fig. 1). Eggs typically oriented horizontally, not placed on end; laid singly or in small clusters on exposed leaf surfaces; often laid on or under prey (Majerus 1994, JAF pers. obs.) 


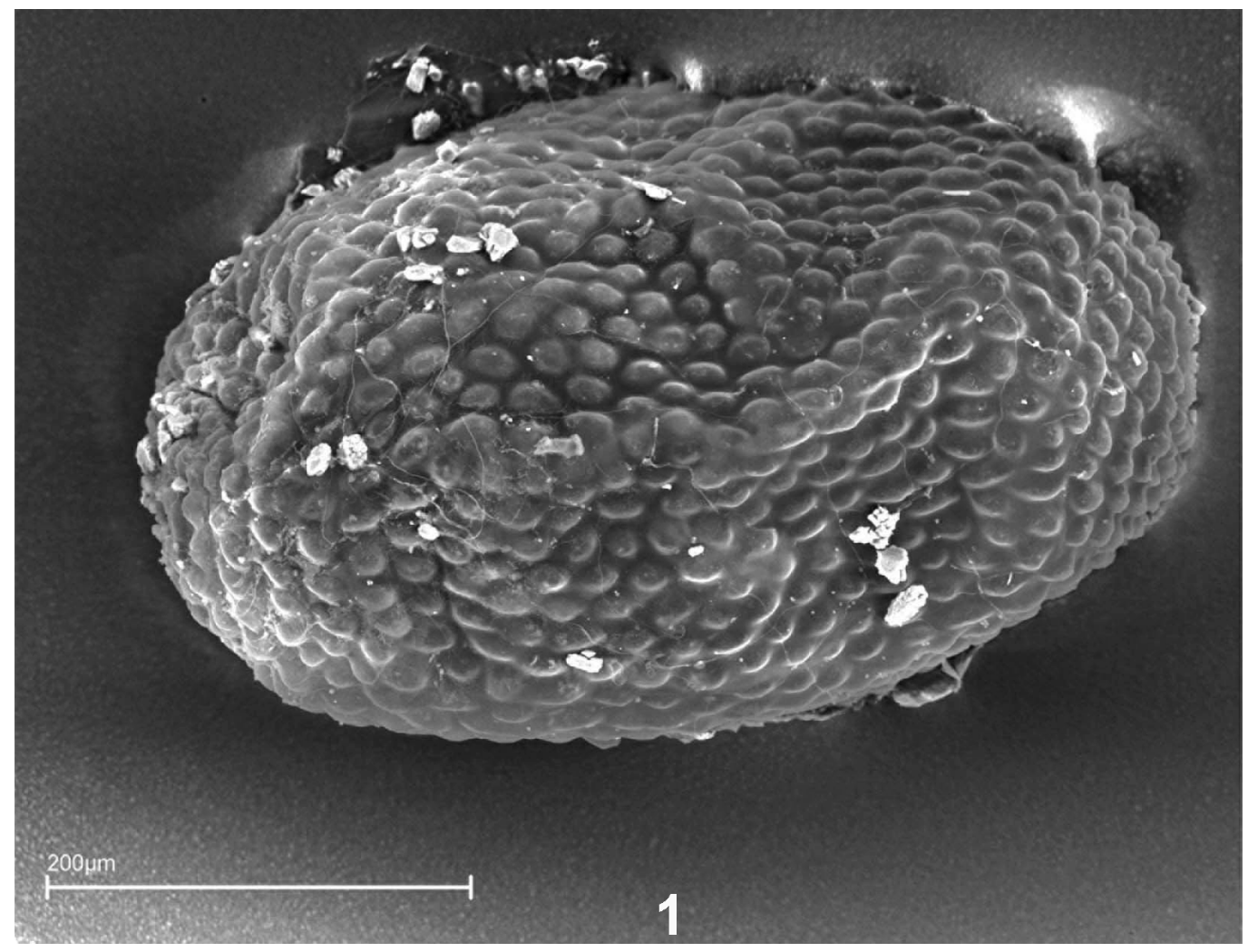

FIGURE 1. Anovia circumclusa (Gorham) egg.

Mature Larva. Length 5-7 mm, (Figs. 2-4). Body ovoid, convex, widest at midpoint, laterally arcuate. Color bright magenta with waxy, white exudate. Dorsal surface moderately setose, finely granulate, covered with waxy exudate (Figs. 2-4). Setae pale, erect, simple, length variable.

Head (Figs. 5-7) prognathous, darkly pigmented, subquadrate, at least twice as long as wide; dorsal and lateral surfaces with several chalazae; seta-like asperities lateral to frontal arms (Fig. 5). Frontal arms vshaped; epicranial stem short, about as wide as long; median endocarina absent. Stemmata arranged in triangular pattern, three on each side. Antenna inserted anteromesad to stemmata, 2-segmented (Fig. 9). Antennomere I robust, length 1/3 width; II small, length subequal to width, sensorium longer than antennomere I. Labrum distinct, subrectangular, weakly bilobed apically (Figs. 5, 7). Mandible triangular, enlarged basally, falcate apically (Figs. 7, 8). Maxillolabial complex retracted (Figs. 6, 7). Maxilla with cardo and stipes fused to form solid, sclerotized structure with slender, arm-like extensions passing anteriorly and laterally around labial palpi; maxillary palpomere 2-segmented; I much broader than long; II about as broad as long (Figs. 6, 7). Mala membranous, transverse. Hypopharyngeal bracon present, well-developed.

Thoracic segments each with a pair of sclerotized plates; meso-and metathorax each with a pair of lateral strumae; struma bearing many chalazae (Figs. 2-4). Legs long, robust, strongly sclerotized dorsally, semimembranous and unpigmented ventrally (Figs. 10-12). Coxa transverse (Fig. 3). Femur robust, almost as broad as long (Figs. 3, 10-12). Tibia elongate, ventral surface distally setose; distal setae flat, clavate (Figs. 10-13). Tarsungulus strongly curved, basal tooth well-developed. Abdomen 10-segmented; segments I-IX with 2 pairs of sclerotized tubercles, 1 pair of chalazate strumae, and 1 pair of annular spiracles; $\mathrm{X}$ bearing pygopod (Fig. 3).

Pupa. Length 4.5-5.5 mm, width $2.5-3.5 \mathrm{~mm}$, exarate (Figs. 14-16). Dorsal habitus elliptical, convex, partially covered in last larval exuvium, attached by cauda to substrate. Color (excluding exuvium) magenta with pale setae (Fig. 15, 16). Dark, stout, bristle-like setae present on dorsal surface of head, pronotum, and humeral angles (Fig. 15). 

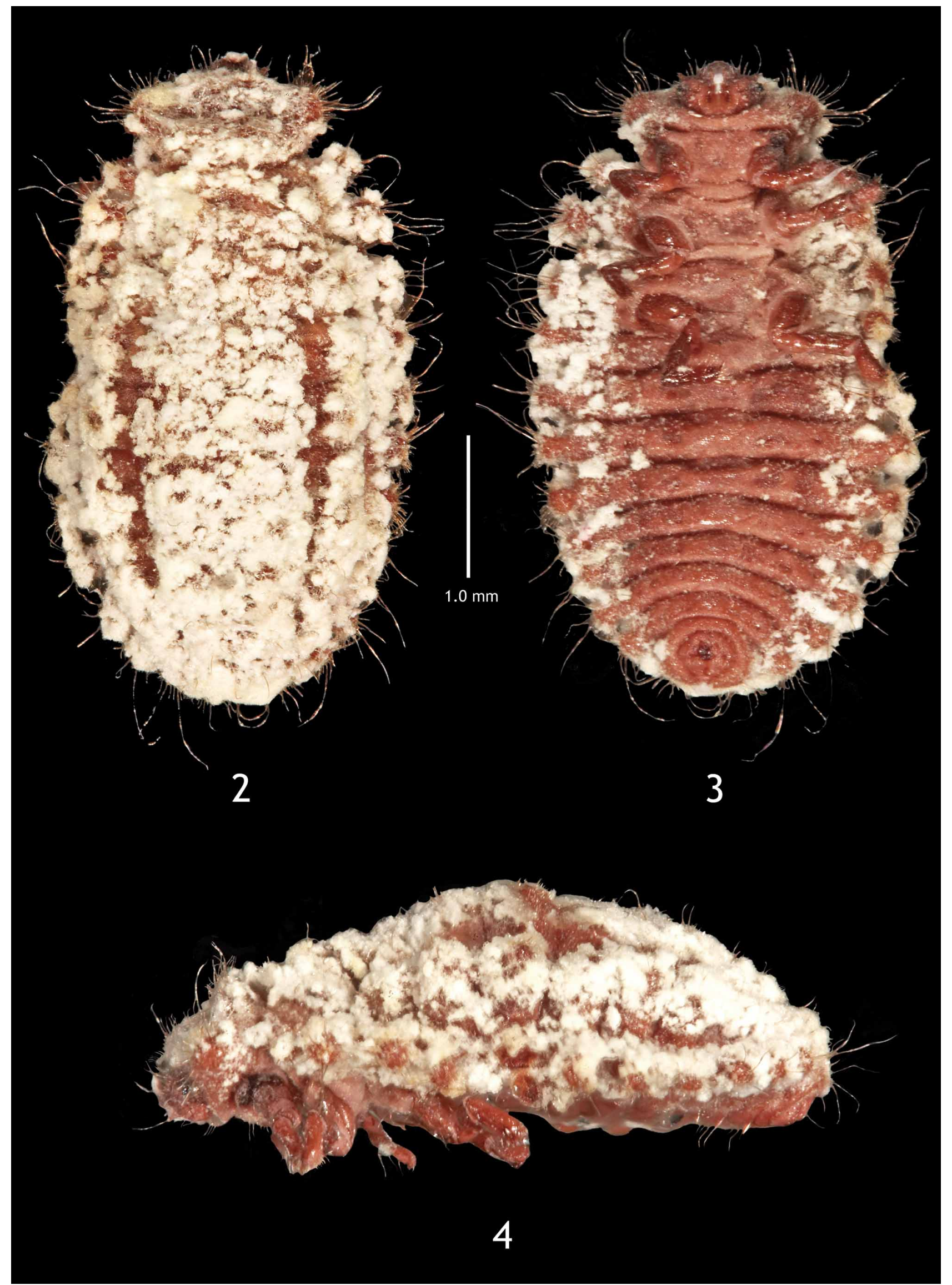

FIGURES 2-4. Anovia circumclusa (Gorham), mature larva. 2. Habitus, dorsal. 3. Habitus, ventral. 4. Habitus, lateral. 


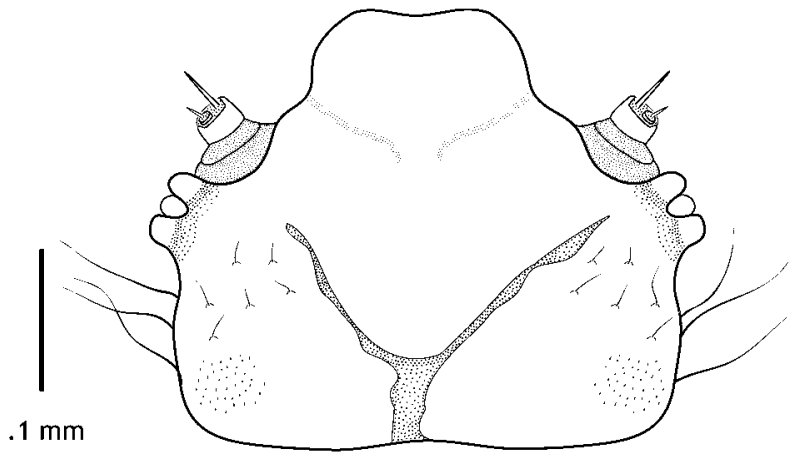

5

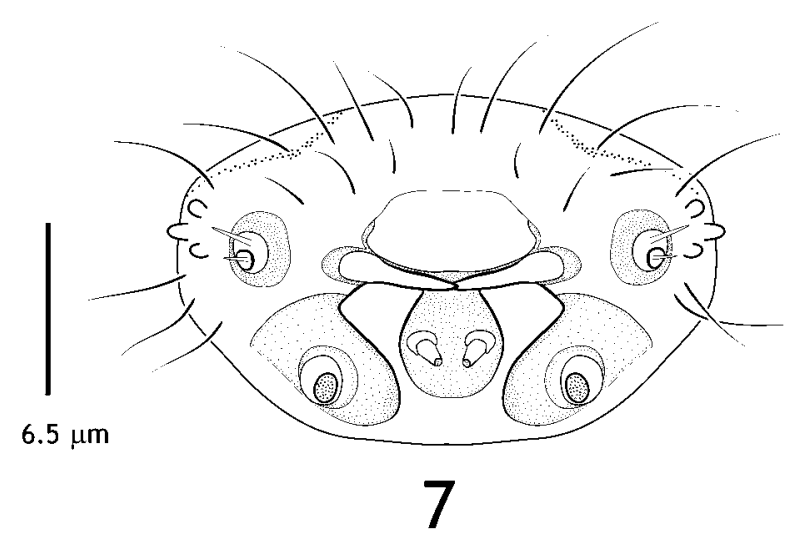

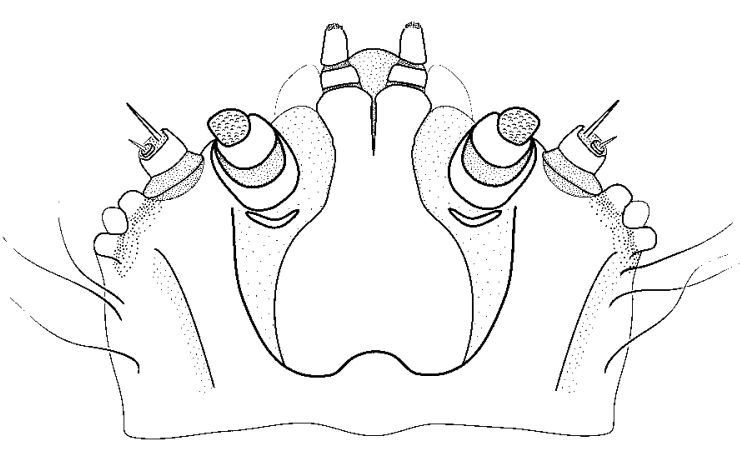

6

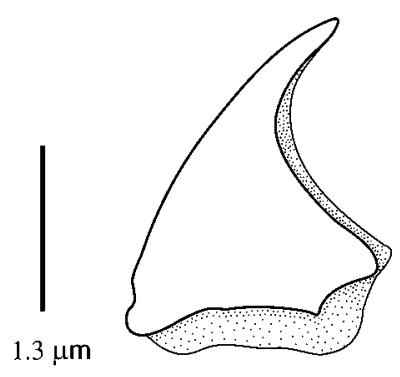

8

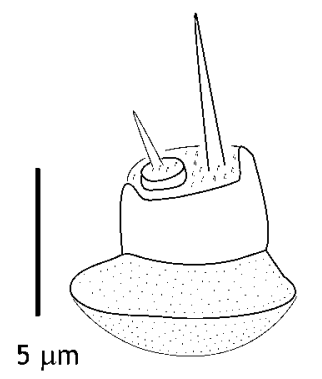

9

FIGURES 5-9. Anovia circumclusa (Gorham), larval head and appendages. 5. Head, dorsal. 6. Head, ventral. 7. Head, anterior. 8. Mandible, left, dorsal . 9. Antenna, left, dorsal.

Head length subequal to width. Antenna short, not extending beyond outer margin of eye, club indistinguishable from flagellum. Apical maxillary palpomere strongly securiform (Fig. 16).

Abdomen with 9 ventrites, I and II reduced and hidden beneath metacoxae; dorsal surface of abdomen with paired transverse tubercles on segments I-VIII; anterolateral angles with annular spiracles; IX with bipartite urogomphi.

Adult. Length 4-4.5 mm. Dorsal habitus hemispherical, laterally arcuate, convex; head strongly deflexed, not visible from above; color variable (Figs. 17-22). Vestiture pale, short, moderately dense, posteriorlydirected.

Head width about twice head length; dorsal surface with evenly spaced, small, shallow punctures; ventral surface narrower; postoccipital margin sinuate (Figs. 23, 24). Eyes large, covered entirely by pale, suberect setae. Antennal insertion exposed, anteromesad to inner eye margin. Antenna with 8 articles; antennomere I asymmetrical, laterally expanded; II subglobose; III-V subequal in length and width; VI-VIII forming loose club, VI-VII asymmetrical, expanded medially; VI about as long as IV + V, VII shorter, VIII broadly tapered apically (Fig. 25). Clypeus small, fused to frons (Figs. 23, 24). Frontoclypeal suture absent. Labrum (Fig. 26) emarginate medially, expanded beyond clypeus laterally. Mandible apically bidentate, teeth sickle-shaped, not in same plane, ventral tooth longer than dorsal one; prosthecal fringe well-developed (Fig. 27). Lacinia slender, elongate, apically setose (Fig. 28). Galea broad, elongate, truncate and apically setose. Maxillary palp 3-segmented, palpifer well-developed; palpomere I elongate, about three times as long as basal width, broadest apically, membranous surface exposed; II apically divergent, mesal edge short, membranous surface exposed; III with distal edge almost twice the length of proximal edge, lateral edge twice the length of mesal 
one (Fig. 28). Labium narrow, labial palp 2-segmented; palpomeres I and II subequal in size, palpomere II gradually narrowed distally to apical sensory area (Fig. 29).

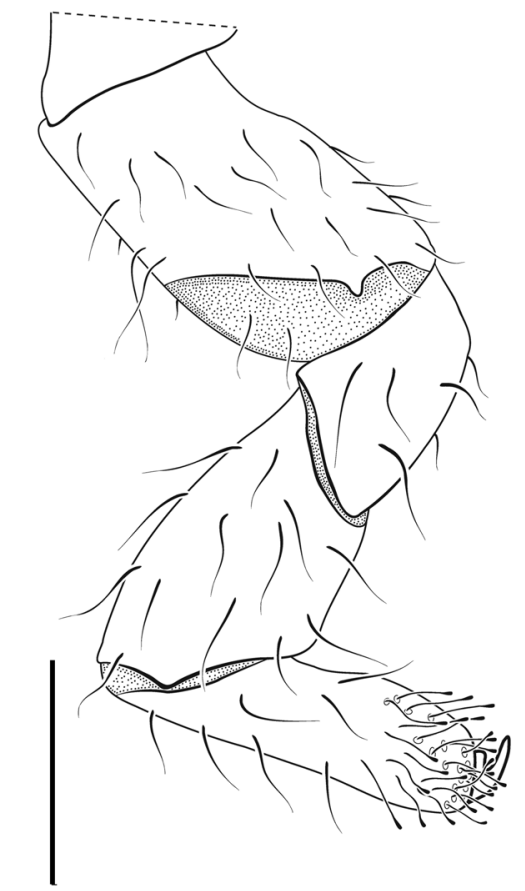

$.25 \mathrm{~mm}$

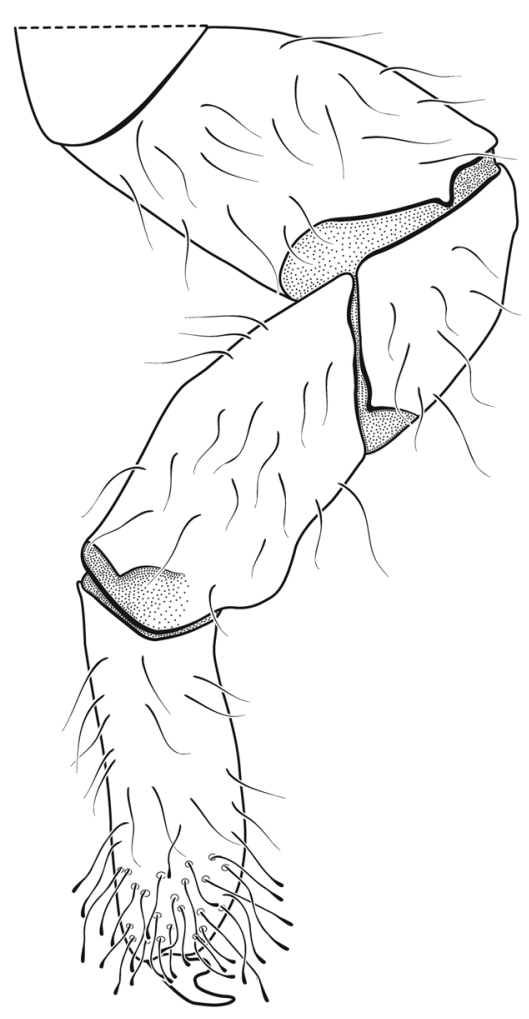

11

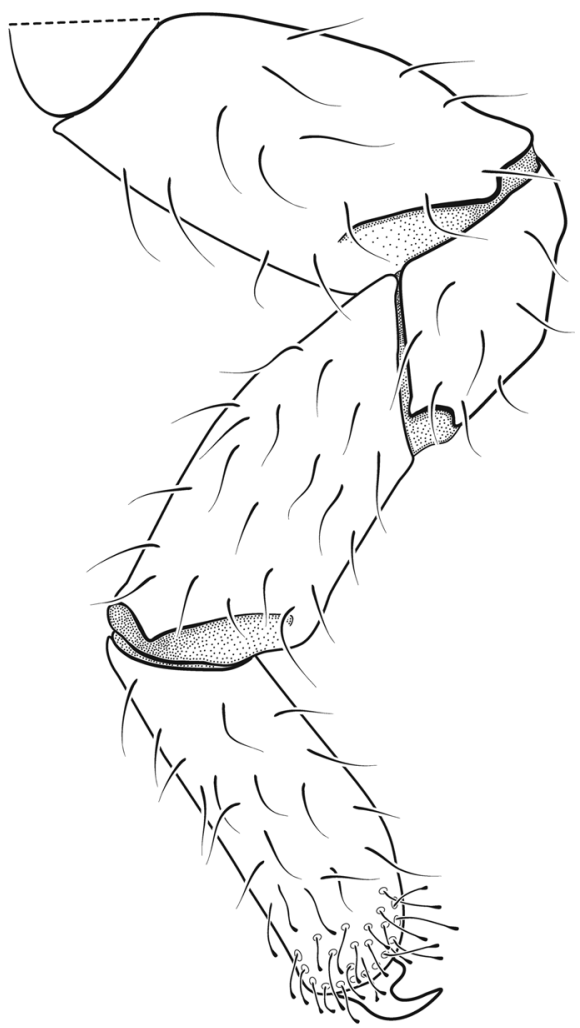

12

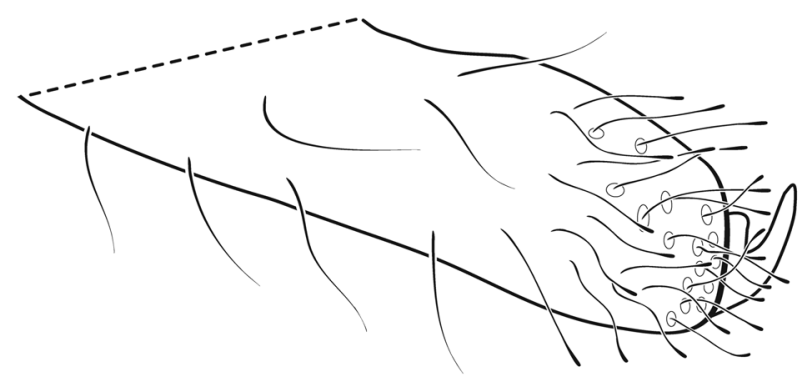

13

FIGURES 10-13. Anovia circumclusa (Gorham), larval legs. 10. Prothoracic leg, left, dorsal. 11. Mesothoracic leg, left, anterior. 12. Metathoracic leg, left, anterior. 13. Prothoracic tibia, left, anterior.

Pronotum with dorsal surface punctate, moderately setose; anterior angles extending forward just beyond lower margin of eye (Figs. 18, 20, 22); anterior edge horizontal just behind head capsule; posterior edge markedly sinuate, slightly notched at scutellum (Fig. 30). Prosternum narrow; prosternal process abruptly raised, rectangular with margins entire; procoxal cavities slightly transverse, closed internally (Fig. 31).

Scutellum triangular. Meso- and metathorax ventrally flattened, pubescent (Fig. 35). Mesoventrite short, narrowest posteriorly. Metaventrite wider than long, finely punctate. Legs (Figs. 32-34) flattened, broad and stout. Femur deeply grooved ventrally for reception of tibia; groove bicarinate, sharply defined, extending almost entire length of femur. Profemur with anterior groove expanded prior to apex. Tibia slightly widened at 
mid-length, ventral surface broader than dorsal, deeply grooved for reception of tarsus; groove bicarinate. Tarsal formula 3-3-3; tarsomeres I and II elongate, lobed ventrally with spongy pubescence; III elongate, cylindrical; male tarsal claw bifid; female tarsal claw with long triangular tooth (Fig. 38).

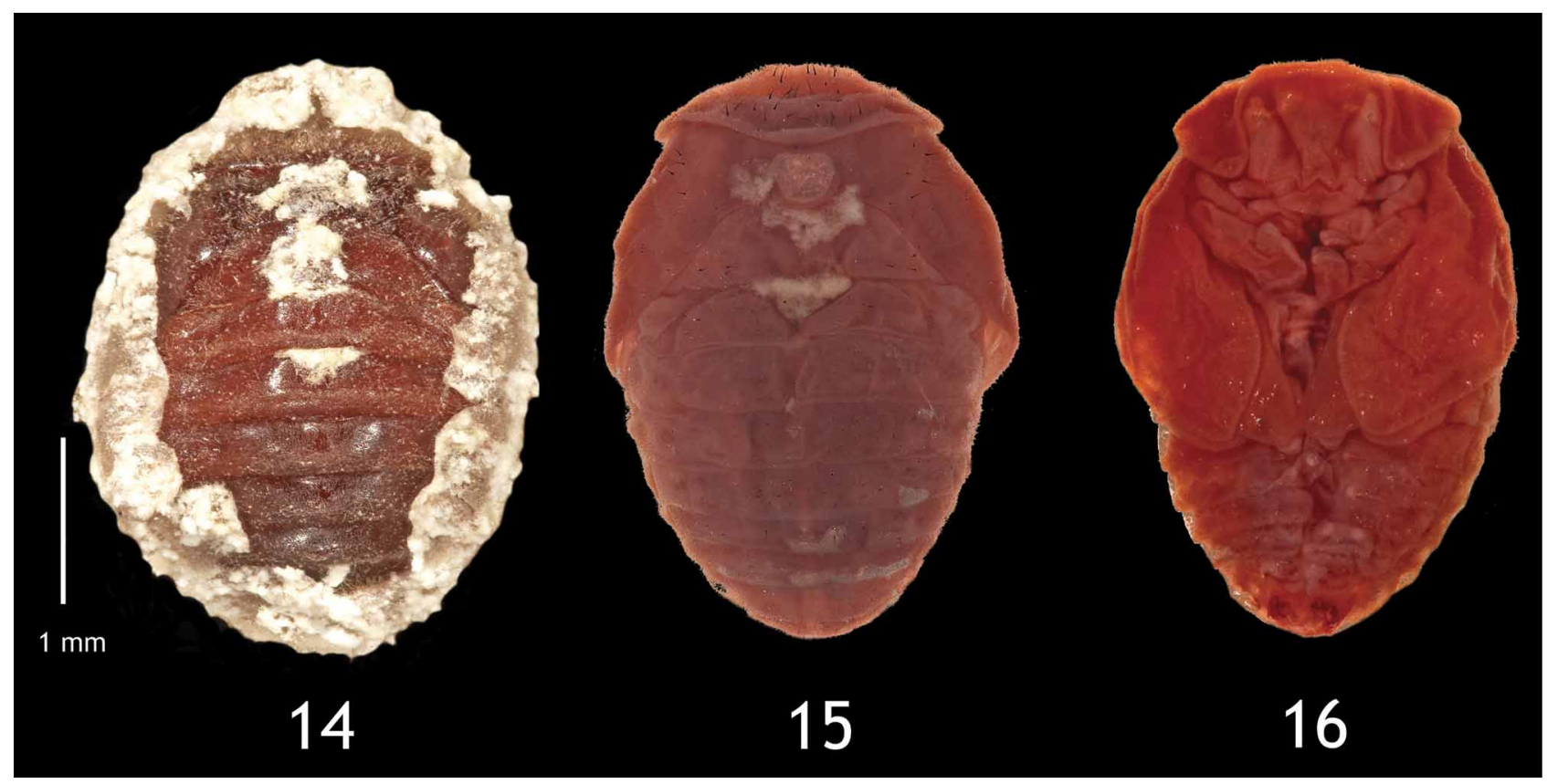

FIGURES 14-16. Anovia circumclusa (Gorham), pupa. 14. Habitus, dorsal, clothed in last larval skin. 15. Habitus, dorsal, last larval skin removed. 16. Habitus, ventral, last larval skin removed.

Elytron subhemispherical to hemispherical, laterally arcuate, finely punctate, non-striate; epipleuron complete to posterior margin, ventral surface moderately rugose. Wing with reduced cantharoid venation, absent in distal half, with strong medial and cubital veins, one anal vein, jugal lobe present. Abdomen with broad, slightly cleft intercoxal process; postcoxal line incomplete to lateral margin; 6 ventrites; I-V rectangular, progressively narrower in width posteriorly; VI narrower, tapering slightly to rounded apex; male with emarginate apex (Fig. 37), female with apex entire. Pygidium subrectangular, setose, broadly rounded apically (Fig. 36).

Male genitalia with phallobase widest anteriorly; basal lobe slender, not extended laterally beyond internal margin of parameres (Figs. 39-41). Sipho as in Fig. 41.

Material examined: see Table 2.

\section{Discussion}

One of the most significant taxonomic questions surrounding Noviini is whether or not the included genera are valid. Gordon $(1972 ; 1985)$ hinted that Rodolia and Anovia should be synonymized because they are virtually impossible to separate on the basis of adult morphological characters, and he cited the larval study by Rees (1947) as the only evidence supporting the recognition of two separate genera. Rees's (1947) study was the first and only attempt to define noviine genera based on larval morphology, but unfortunately only one species of Anovia was examined. The brief description of A. virginalis in that study was used to characterize the larvae for the entire genus. As a result, subsequent authors continued to recognize Rodolia and Anovia as distinct genera based entirely on the presence (Rodolia) or absence (Anovia) of larval antennomere II (Gordon 1972; Gordon 1985; Rees et al. 1994). Examination of the larva, pupa, and adult of A. circumclusa supports its inclusion in Noviini. The larva has the cardo and stipes fused to form slender arms that encompass the 
labial palpi, and each abdominal tergum bears two pairs of sclerotized tubercles (Rees 1947, Rees et al. 1994). The pupa has dense, fine, pale setae on the apex of the hind wing and bipartite urogomphi on abdominal tergum IX (Phuoc \& Stehr 1974). The species is native to South America and the adult has an incomplete postcoxal line: a taxonomic feature that Gordon $(1972,1985)$ used to differentiate Anovia from Rodolia. Examination of over 1500 specimens of Noviini by the senior author has demonstrated that this character is not sufficient to separate the genera. The postcoxal line in Noviini is variable, though; some Rodolia species also have an incomplete postcoxal line. Furthermore, the larva of $A$. circumclusa lacks the critical feature that Rees (1949) proposed to diagnose the genus, i.e, the two-segmented larval antenna. Thus, given the extreme morphological similarity of both genera, the validity of Anovia is more questionable than ever. A phylogenetic analysis, ideally one including both adult and larval characters, is needed to resolve this issue.

TABLE 2. Material examined.

\begin{tabular}{|c|c|c|c|c|c|}
\hline Label 1 & Label 2 & Label 3 & Label 4 & $\#$, gender & Depository \\
\hline $\begin{array}{l}\text { La Celba } \\
\text { Honduras } \\
\text { June } 28\end{array}$ & Chnodes sp. & $\begin{array}{l}\text { FJ Dyer } \\
\text { coll. }\end{array}$ & $\begin{array}{l}\text { Anovia } \\
\text { circumclusa } \\
\text { (Gorham) } \\
\text { det. R. Gordon }\end{array}$ & 1 , male & USNM \\
\hline $\begin{array}{l}\text { Tampico } \\
\text { Mex } 612\end{array}$ & $\begin{array}{l}\text { EA Schwarz } \\
\text { Collector }\end{array}$ & & $\begin{array}{l}\text { Anovia } \\
\text { circumclusa } \\
\text { (Gorham) } \\
\text { det. R. Gordon }\end{array}$ & 2 , male & USNM \\
\hline $\begin{array}{l}\text { Tampico } \\
\text { Mex } 2212\end{array}$ & $\begin{array}{l}\text { EA Schwarz } \\
\text { Collector }\end{array}$ & & $\begin{array}{l}\text { Anovia } \\
\text { circumclusa } \\
\text { (Gorham) } \\
\text { det. R. Gordon }\end{array}$ & 1 , female & USNM \\
\hline $\begin{array}{l}\text { Tampico } \\
\text { Mex } 1412\end{array}$ & $\begin{array}{l}\text { EA Schwarz } \\
\text { Collector }\end{array}$ & & $\begin{array}{l}\text { Anovia } \\
\text { circumclusa } \\
\text { (Gorham) } \\
\text { det. R. Gordon }\end{array}$ & 1 , female & USNM \\
\hline $\begin{array}{l}\text { Tegucigalpa } \\
\text { Hond }\end{array}$ & $\begin{array}{l}\text { June } \\
23,18\end{array}$ & $\begin{array}{l}\text { FJ Dyer } \\
\text { coll. }\end{array}$ & $\begin{array}{l}\text { Anovia } \\
\text { circumclusa } \\
\text { (Gorham) } \\
\text { det. R. Gordon }\end{array}$ & 1 , male & USNM \\
\hline $\begin{array}{l}\text { Tegucigalpa } \\
\text { Honduras } \\
\text { VI. 12. } 18\end{array}$ & $\begin{array}{l}\text { F. J. Dyer, Col. } \\
\text { No. } 40425\end{array}$ & $\begin{array}{l}\text { Anovia } \\
\text { circumclusa } \\
\text { (Gorham) } \\
\text { det. R. Gordon }\end{array}$ & & 1 , male & USNM \\
\hline $\begin{array}{l}\text { Tegucigalpa } \\
\text { Honduras } \\
\text { IV. } 27.18\end{array}$ & $\begin{array}{l}\text { F. J. Dyer, Col. } \\
\text { No. } 41319 \\
41430\end{array}$ & $\begin{array}{l}\text { Anovia } \\
\text { circumclusa } \\
\text { (Gorham) } \\
\text { det. R. Gordon }\end{array}$ & & $\begin{array}{l}1, \text { male } \\
1, \text { female }\end{array}$ & USNM \\
\hline $\begin{array}{l}\text { FLORIDA: Miami- } \\
\text { Dade Co. }\end{array}$ & Miami S30 T53 R42 & $\begin{array}{l}\text { 13-IX-2007 } \\
\text { coll. O. Garcia }\end{array}$ & $\begin{array}{l}\text { on Quercus } \\
\text { virginiana } \\
\text { [Fagaceae]. A } \\
\text { Diomus roseicollis } \\
\text { was in the same } \\
\text { collection] }\end{array}$ & 1 , male & FSCA \\
\hline $\begin{array}{l}\text { Port Everglades, Fort } \\
\text { Lauderdale, on } \\
\text { leguminous weeds } \\
\text { infested with Icerya } \\
\text { genistae }\end{array}$ & & & & 1 , male & USNM \\
\hline
\end{tabular}




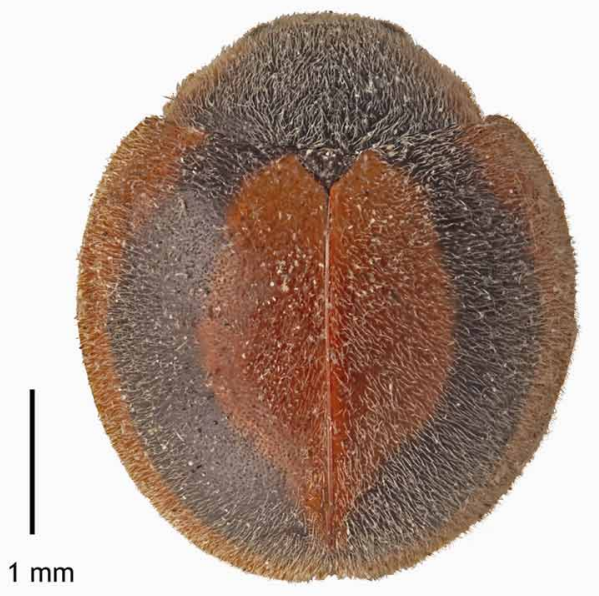

17

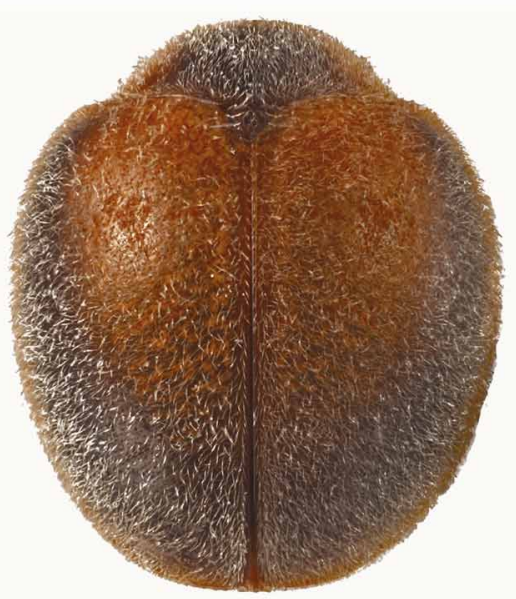

19

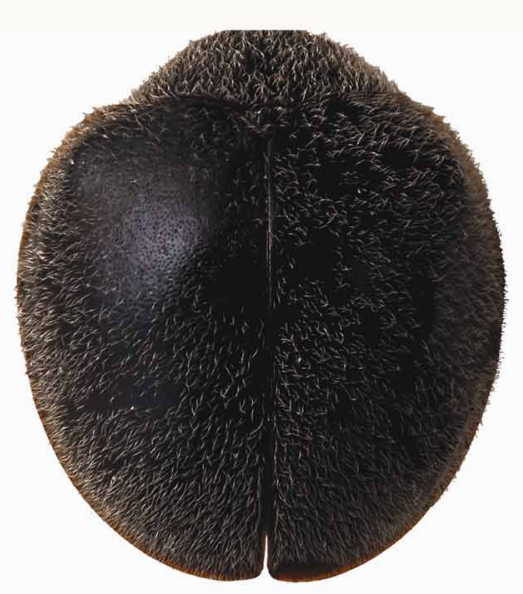

21

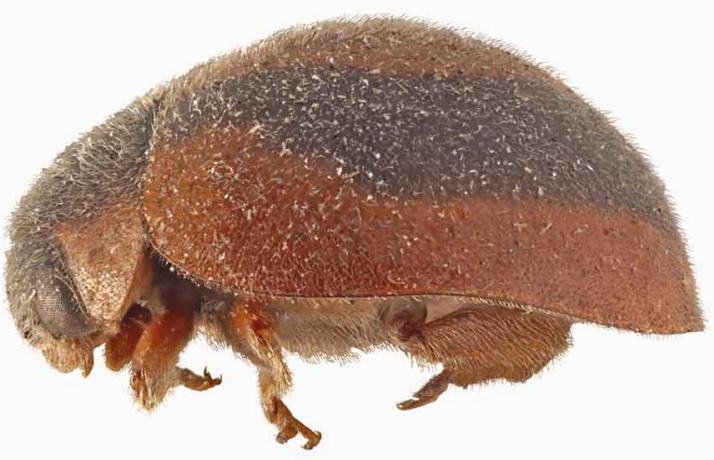

18

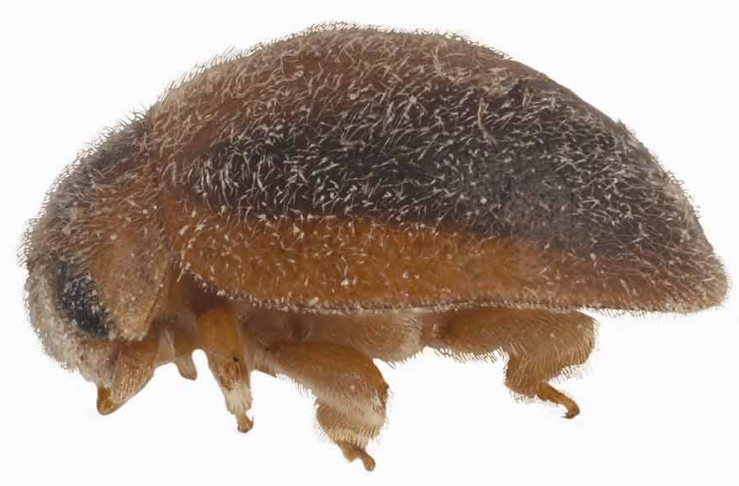

20

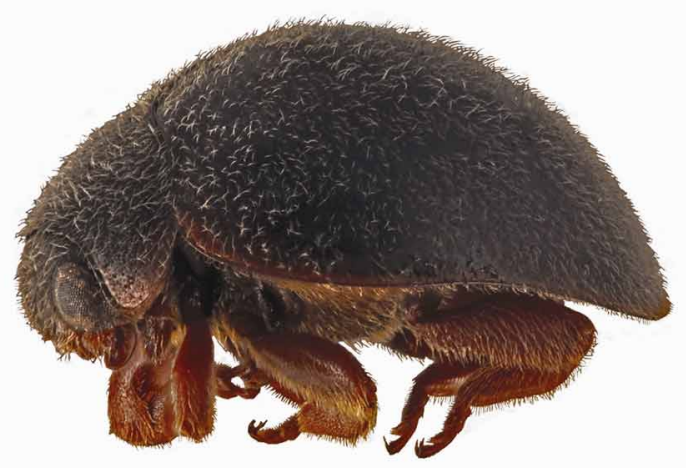

22

FIGURES 17-22. Anovia circumclusa (Gorham), adult. 17. Habitus, dorsal. 18. Habitus, lateral. 19. Habitus, dorsal. 20. Habitus, lateral. 21. Habitus, dorsal. 22. Habitus, lateral. 


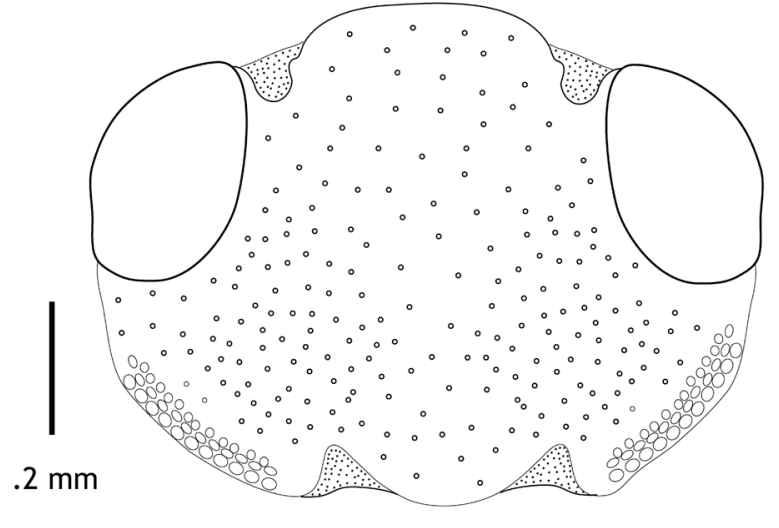

23

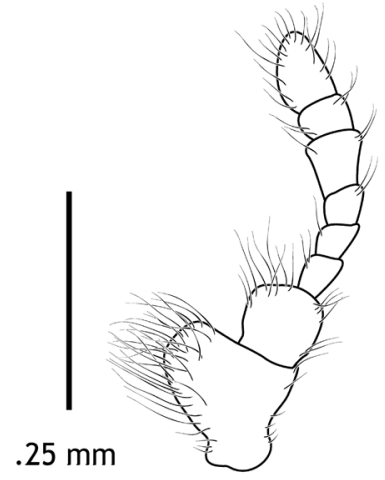

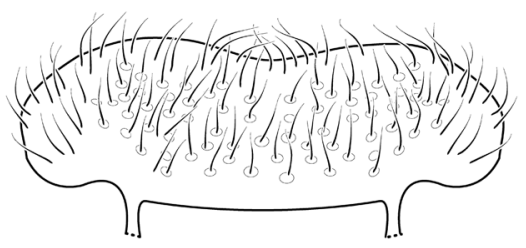

26

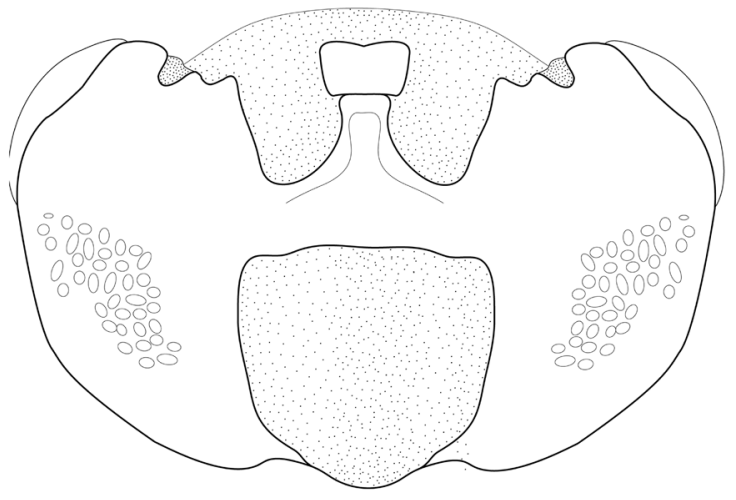

24
25

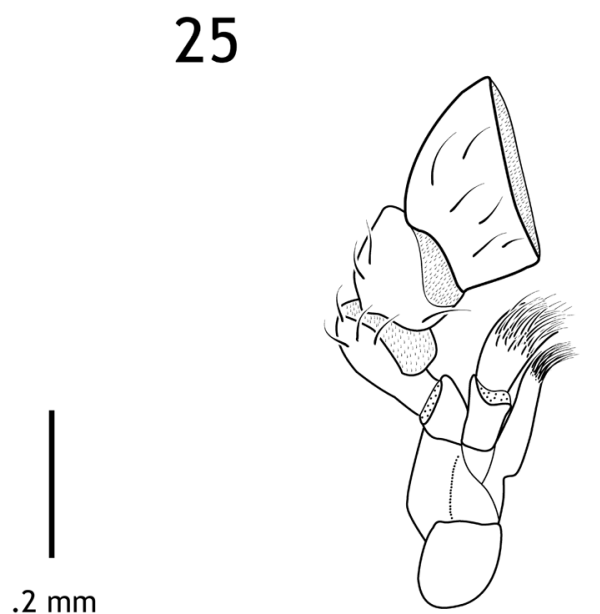

28

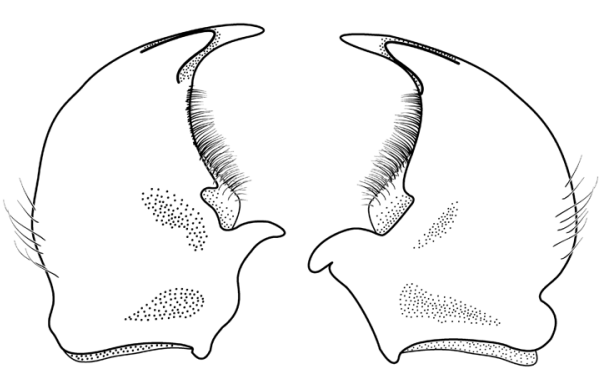

27

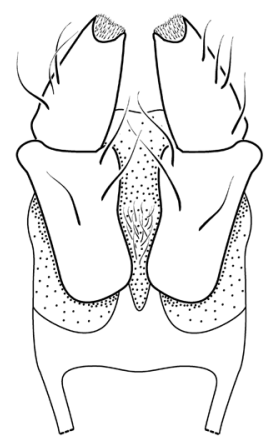

29

FIGURES 23-29. Anovia circumclusa (Gorham), adult head and appendages. (Note: setae and eye facets omitted for clarity.) 23. Head, dorsal. 24. Head, ventral. 25. Antenna, left, dorsal. 26. Labrum, dorsal. 27. Mandibles, dorsal. 28. Maxilla, left, dorsal. 29. Labium, ventral.

Noviine larvae are very difficult to identify in the field. Besides their overall similarity, all noviine larvae are covered with powdery, granular wax that obscures most aspects of their anatomy (Figs. 2-4). The wax threads apparently are secreted from the bases of hollow, pointed spicules on the dorsal surface of the larval body; the spicules are used for support as the wax thread is secreted upward (Pope 1979).

Another taxonomic problem encountered with adult noviines, and coccinellids in general, is intraspecific 
color variation. Gordon (1972) noted extensive elytral pattern variation within Anovia species, but identification keys for the genus still rely heavily on color patterns. Examination of the majority of the world's holdings of Noviini by the senior author confirmed that coloration is not a reliable feature for diagnosing any species in the tribe, including members of Anovia. When representatives of A. circumclusa are viewed dorsally side-by-side, a smooth coloration gradient becomes apparent. The elytral pattern ranges from carmine red with a discrete black ring (Figs. 17, 18) to almost entirely black (Figs. 21, 22). Intermediate forms have orange elytra with a broad, vaguely defined dark area laterally and posteriorly (Figs. 19, 20). A similar gradation in elytral color patterns occurs in A. punica.
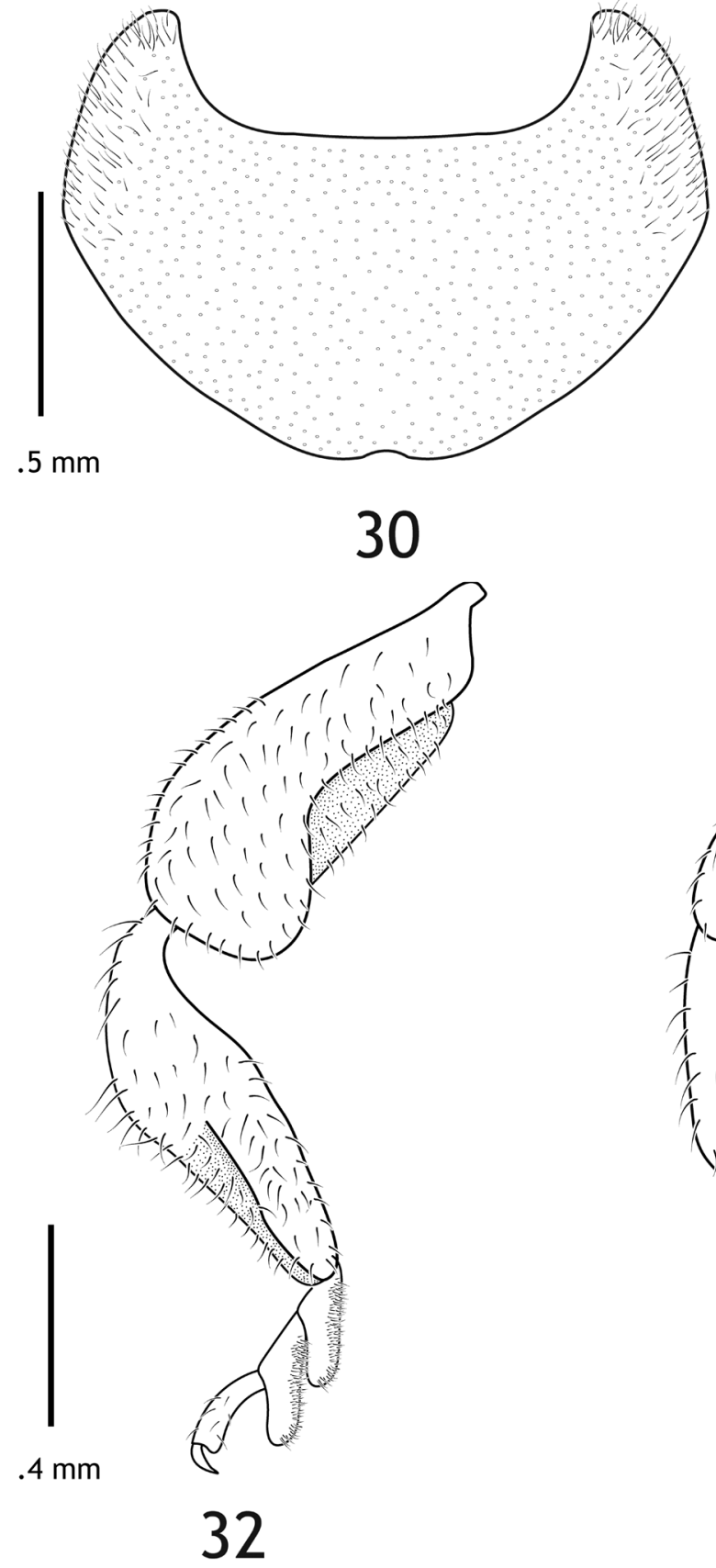

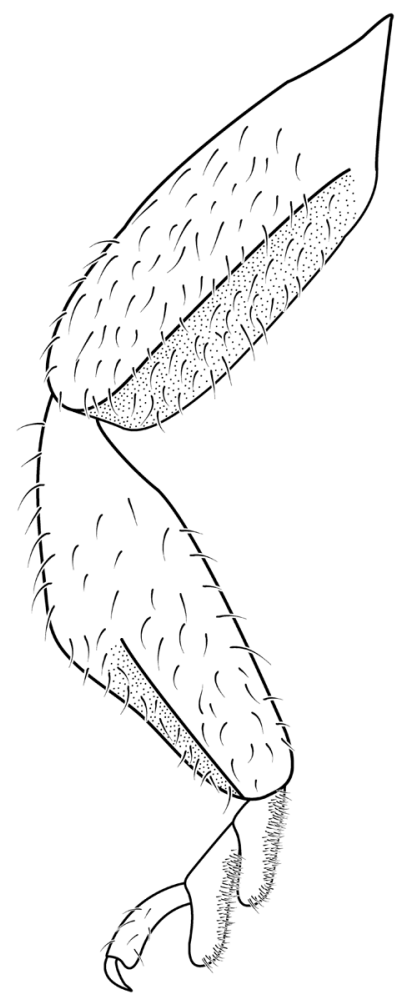

33
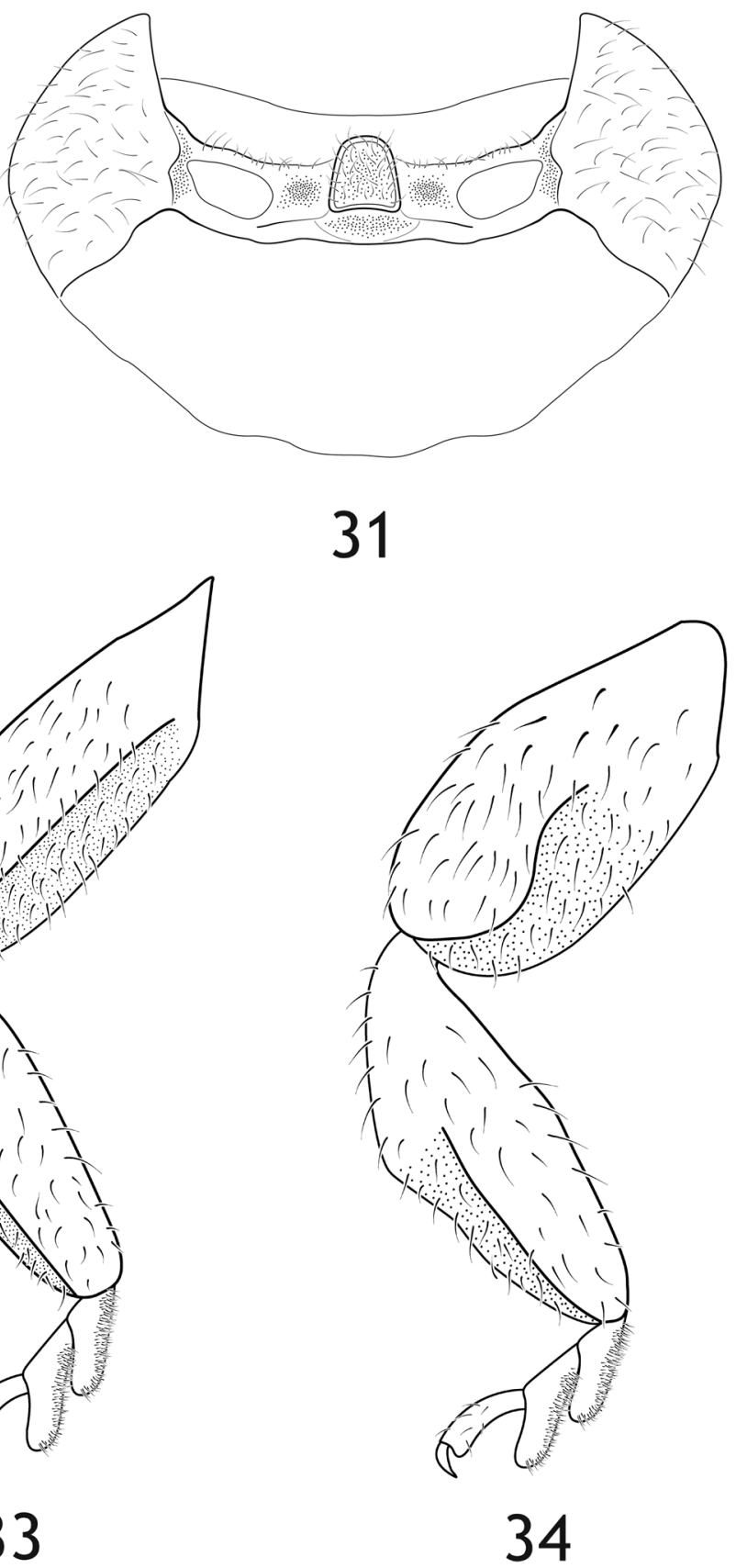

FIGURES 30-34. Anovia circumclusa (Gorham), adult prothorax and appendages. 30. Pronotum, dorsal. 31. Prosternum, ventral. 32. Prothoracic leg, left, anterior. 33. Mesothoracic leg, left, anterior. 34. Metathoracic leg, left, anterior. 


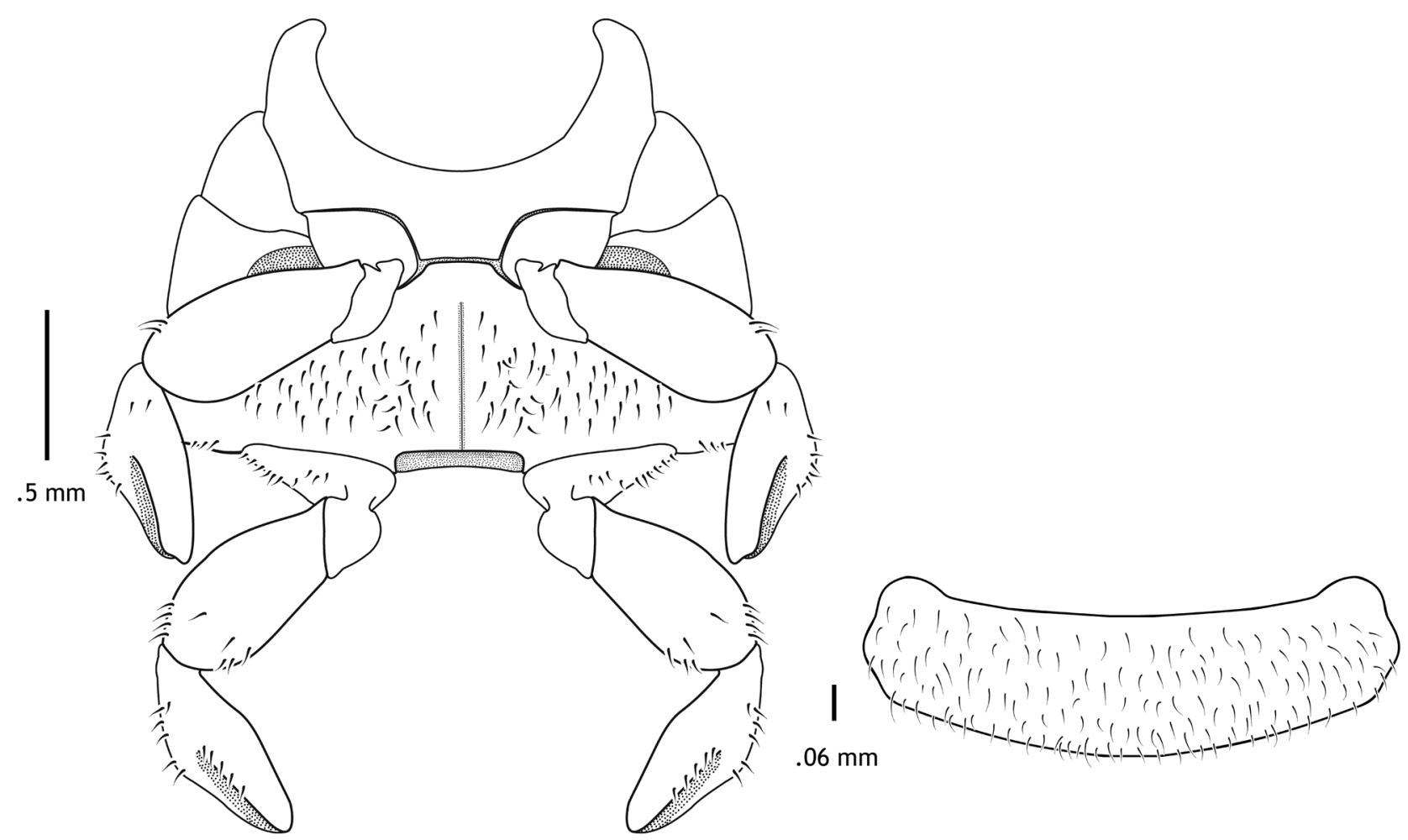

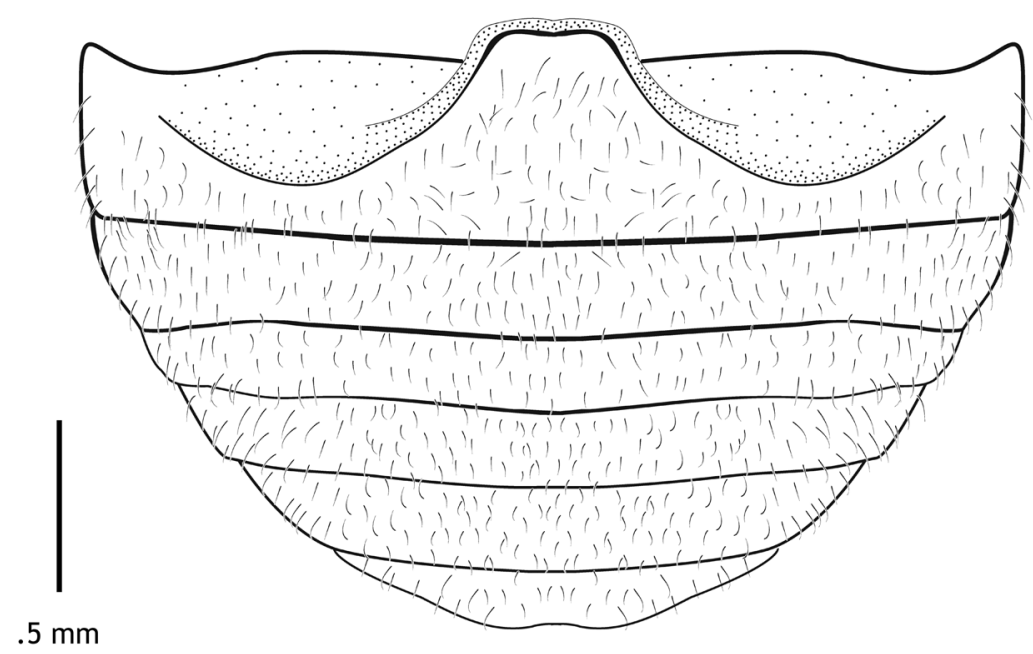

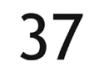

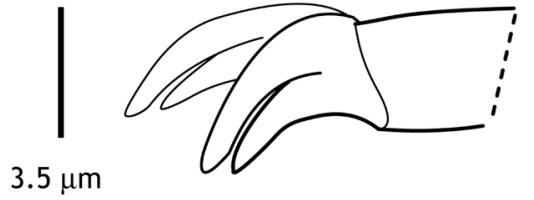

38

FIGURES 35-38. Anovia circumclusa (Gorham), adult pterothorax, abdomen, and appendages. 35. Pterothorax, ventral. 36. Pygidium, dorsal. 37. Abdomen, ventral. 38. .Metathoracic tarsal claw of female, left, posterior.

A number of factors contribute to the wide array of elytral color patterns associated with Coccinellidae. Much of the variation (number of spots, spot position, spot size and shape) is genetic; however, there are other factors that are known to affect coloration (Majerus 1994; Honěk 1996). Honěk (1996) provided a review of temporal and geographic variability in lady beetles, noting that light-colored populations tend to occur in arid regions while darker pigmentation is more common in humid areas. Gordon (1972) noted that in the neotropical Zenoria, elytral pattern differences can sometimes be linked to specimen maturity; however, neither habitat nor age seems correlated with the color variation observed in Noviini. The familiar aposematic 
colors of many coccinellids often advertise chemical defenses (Bezzerides et al. 2007; King \& Meinwald 1996), but it is unknown whether this is true for Noviini.
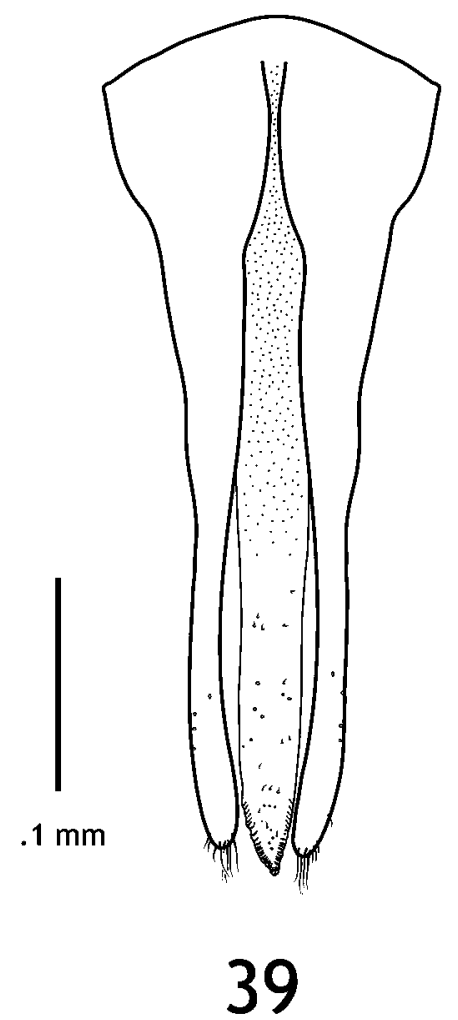

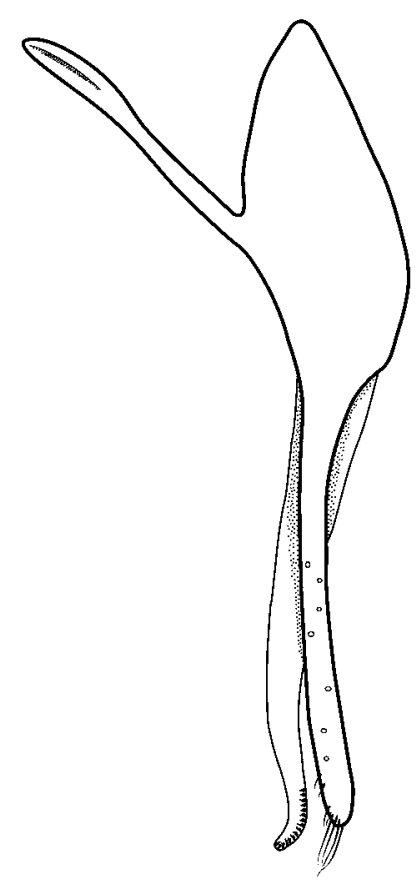

40

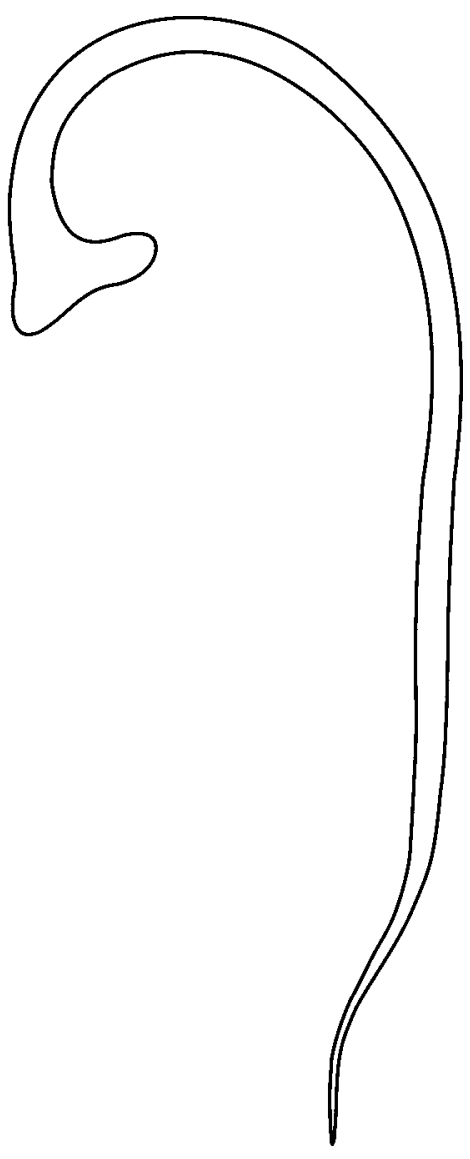

41

FIGURES 39-41. Anovia circumclusa (Gorham), adult male genitalia, redrawn with permission from Zootaxa 1720: 66-68 (Forrester \& Vandenberg 2008). 39. Aedeagus, dorsal. 40. Aedeagus, lateral. 41. Sipho, lateral.

\section{Acknowledgments}

We thank Divina Amalin and Amy Roda, USDA, APHIS, Plant Protection and Quarantine, and Michael Thomas, FSCA, for kindly sending Florida-collected specimens of A. circumclusa. We especially thank Divina Amalin for sending laboratory-reared eggs, pupae, and additional adult specimens. We thank Nathan P. Lord (University of New Mexico) for the ESEM image of the egg. The senior author is grateful to Ralph Holzenthal (University of Minnesota) for valuable instruction in digital illustration. We also thank Dave Nickle (SEL), Al Norrbom (SEL), Adam Ślipiński (CSIRO), and Wioletta Tomaszewska (Muzeum i Instytut Zoologii PAN) for providing thorough reviews of this manuscript. Darren Pollock (ENMU) and an anonymous reviewer also provided helpful comments. This work was supported by Hatch Project GEO 00787 (to J.V. McHugh) and N.S.F. PEET grant DEB-0329115 (to J.V. McHugh, M. F. Whiting, and K. Miller).

\section{Literature cited}

Balduf, W. V. (1935) The Bionomics of Entomophagous Coleoptera. E. W. Classey, Middlesex. 222 pp. 
Blackwelder, R. E. (1945) Checklist of the Coleopterous Insects of Mexico, Central America, the West Indies, and South America. Part 3. United States National Museum Bulletin 185. 188pp.

Bezzerides, A. L., McGraw, K. J., Parker, R. S., \& J. Husseini (2007). Elytra color as a signal of chemical defense in the Asian ladybird beetle Harmonia axyridis. Behavioral Ecology and Sociobiology, 61, 1401-1408.

Caltagirone, L. E. \& Doutt, R. L. (1989) The history of the Vedalia Beetle importation into California and its impact on the development of biological control. Annual Review of Entomology, 34, 1-16.

Casey, T. L. (1908) Notes on the Coccinellidae. The Canadian Entomologist, 40, 393-421.

Emden, van F.L. (1949) Larvae of British beetles. VII. (Coccinellidae). Entomologist's Monthly Magazine, 85, $265-283$.

Forrester, J.A. \& Vandenberg, N.J. (2008) First Florida records for Anovia circumclusa (Gorham) (Coleoptera: Coccinellidae: Noviini): A natural enemy of Icerya genistae Hempel (Hemiptera: Margarodidae). Zootaxa, 1720, $66-68$.

Gage, J.H. (1920) The larvae of the Coccinellidae. Illinois Biological Monographs, 6(4), 62 pp.

Gordon, R.D. (1971) A revision of the genus Zenoria Mulsant (Coleoptera: Coccinellidae). Smithsonian Contributions to Zoology, 86, 1-22.

Gordon, R.D. (1972) The tribe Noviini in the New World (Coleoptera: Coccinellidae). Journal of the Washington Academy of Sciences, 62(1), 23-31.

Gordon, R.D. (1985) The Coccinellidae (Coleoptera) of America north of Mexico. Journal of the New York Entomological Society, 93(1), 654-678.

Gorham, H.S. (1899) Insecta. Coleoptera. Supplement to Endomychidae and Coccinellidae. Biologia CentraliAmericana. R. H. Porter, London, 276 pp, 13 pl.

Grafton-Cardwell, B. (2002) Stages of the Cottony Cushion Scale (Icerya purchasi) and its Natural Enemy, the Vedalia Beetle (Rodolia cardinalis). University of California Division of Agriculture and Natural Resources 1- 3. Resources, Publication 8051, 1-3. Available from http://ucanr.org/freepubs/docs/8051.pdf (accessed 15 December 2008)

Honěk, A. (1996). Variability and Genetic Studies. In: I. Hodek \& A. Honěk (Eds.) Ecology of Coccinellidae. Kluwer Academic Publishers, Dordrecht, pp. 33-57.

Hodges, G. (2006) Pest Alert: Icerya genistae (Hemiptera: Margarodidae), a new exotic scale insect for Florida. Pest Alert 1-3. Available from http://www.doacs.state.fl.us/pi/enpp/ento/c.genistae.html (accessed 15 December 2008)

Kamiya, H. (1964) Comparative morphology of larvae of the Japanese Coccinellidae, with special reference to the tribal phylogeny of the family (Coleoptera). Memoirs of the Faculty of Fukui University, Series II, Natural Science, 14, 83-100.

Kamiya, H. (1966) On the Coccinellidae attacking the scale insects and mites in Japan and the Ryukus. Mushi, 39, 65-93.

Kawaguchi, T. (1935) On Rodolia concolor Lewis. The Insect World, 34(6), 208.

King, G.A. \& Meinwald, J. (1996). Review of the defensive chemistry of coccinellids. Chemical Reviews, 96(3), $1105-1122$.

Klausnitzer, B. \& Schulze, J. (1975) The larva of Novius cruentatus (Coleoptera: Coccinellidae). Deutsche Entomologische Zeitschrift, 4-5, 359-361.

Koebele, A. (1892) Report on Condition of Newly Introduced Species in California. Report on the Importation of Parasites and Predaceous Insects by the California State Board of Horticulture 13-15.

Korschefsky, R. (1931) Pars 118, Coccinellidae. Coleopterorum Catalogus, W. Junk, Berlin, 224 pp.

Leng, C.W. (1920) Catalogue of the Coleoptera of America, north of Mexico. Mount Vernon, New York, 470 pp.

LeSage, L. (1991) Coccinellidae (Cucujoidea), the lady beetles, ladybirds. In: F. W. Stehr, (Ed.) Immature Insects. Volume II. Kendall/Hunt. Dubuque, Iowa, pp. 485-494.

Majerus, M.E.N. (1994) Ladybirds. Harper Collins, London, 367 pp.

Mulsant, M. E. (1846) Histoire naturelle des Coleopteres de France: Sulcicolles- Securipalpes. Paris, 280 pp.

Olliff, M.S. (1895) Entomological notes-A friendly new ladybird. Agricultural Gazette of New South Wales, 6, 30-31.

Perris, M.E. (1862) Histoire des insectes du pin maritime: Supplément aux Coléoptères et rectifications. Annales de la Société Entomologique de France, 4(2), 173-243.

Phuoc, D.T. \&. Stehr, F.W.. (1974) Morphology and taxonomy of the known pupae of Coccinellidae (Coleoptera) of North America, with a discussion of phylogenetic relationships. Contributions of the American Entomological Institute, 10(6), 31-123.

Pope, R.D. (1979) Wax production by coccinellid larvae (Coleoptera). Systematic Entomology, 4, 171-196.

Priore, R. (1963) Studio morfo-biologico sulla Rodolia cardinalis Muls. Bolletino del Laboratorio de Entomologia Agraria Filippo Silvestri di Portici, 31, 63-193.

Rees, B.E. (1947) Taxonomy of the larvae of some North American Noviini (Coleoptera, Coccinellidae). The PanPacific Entomologist, 23, 113-119.

Rees, B.E., Anderson, D.M., Bouk, D., \& Gordon, R.D. (1994) Larval key to genera and selected species of North American Coccinellidae (Coleoptera). Proceedings of the Entomological Society of Washington, 96, 387-413. 
Savoïskaya, G.I. \& Klausnitzer, B. (1973) Morphology and taxonomy of the larvae with keys for their identification. In: I. Hodek (Ed.), Biology of Coccinellidae. Dr. W. Junk N. V. Prague, pp. 36-53.

Savoïskaya, G.I. (1983) Larvae of coccinellids (Coleoptera, Coccinellidae) of the USSR fauna. Institute of the USSR Academy of Sciences pp. 36-53.

Sasaji, H. (1968) Descriptions of the coccinellid larvae of Japan and the Ryukus (Coleoptera). Memoirs of the Faculty of Fukui University, Series II, Natural Science, 18, 93-135.

Ślipiński, S.A. (2007) Australian Ladybird Beetles (Coleoptera: Coccinellidae): their biology and classification. Australian Biological Resources Study, Canberra. 141 pp.

Vandenberg, N.J. (2002) Family 93. Coccinellidae Latreille 1807. In: R.H. Arnett, Michael C. Thomas, Jr., P. E. Skelley, and J. H. Frank (Eds), American Beetles Volume II: Scarabaeoidea through Curculionoidea. CRC Press LLC Boca Raton, USA, pp. 371-389.

Weise, J. (1887) Ueber die Lebenweise von Novius cruentatus Muls. Deutsche Entomologische Zeitschrift, 31, 181-183.

Weise, J. (1885) Bestimmungs-Tabellen der Eeuropaischen Coleopteren. II. Heft. Coccinellidae. II. Auflage mit Berucksichtigung der Arten aus dem Nordlichen Asien. Mödling, 83 pp.

Wickham, H.F. (1905) New species of Coleoptera from the Western United States. The Canadian Entomologist, 37, $165-171$ 